\title{
Multidisciplinary Approach of a Didactic Strategy for the Second Year of High School
}

\author{
María de los Ángeles Montiel Montoya \\ Department of Chemistry, National Preparatory School No. 4, National Autonomous University of Mexico, CDMX 11870, Mexico
}

\begin{abstract}
During the chemistry week, "A musical, literary, ecological and chemical show" was performed with the participation of students of 552 and 553 groups of the National Preparatory School of National Autonomous University of Mexico. The students had the opportunity to put into action some skills related to reading, research, playing musical instruments and performance. This document relates each activity with the subjects connected in a transversal way (Greco-Latin etymologies, biology IV, health science, universal literature), previous subjects (aesthetic and artistic education, Spanish literature, geography and history), later subjects (history and Iberoamerican and Mexican literature). This show achieved the symbiosis between natural and social sciences and art in an entertaining learning environment.
\end{abstract}

Key words: Chemistry, high school, multidiscipline, natural and social sciences, arts.

\section{Introduction}

Nowadays, teachers should acquire new teaching strategies so the students develop knowledge, abilities and skills that connect the subjects of a specific academic year at the High School.

In the High School Academic Meetings called "Multidisciplinary views: new approaches for the teaching transformation”, teachers show the projects, progress, thoughts and proposals that include strategies with a multidisciplinary view. In the other hand, in the teaching analysis seminar (SADE), four guiding axes are the base for the curricular change happening right now. The second axis establishes: "Stimulate the participating attitude of the teacher when he realizes he's in charge of his own training and the search, selection and elaboration of different materials". The third axis establishes: "Boost the meaning of didactic innovation based on aspects like the transversal proposal to cope with some challenges of the student education". These two axes were applied in this didactic strategy.

Corresponding author: María de los Angeles Montiel Montoya, bio-pharmaceutical chemist, research field: learning strategies.
The didactic proposal lies in these principles [1].

The goal of the activity was to create a project, during the chemistry week, in which some subjects are related in a transversal way in the second year of High School, and previously in the first year. This project should be an answer to the change in the teaching culture asked in the teaching analysis seminar.

\section{Methods}

(1) The author looked for literary texts which could be connected with different subjects that the students are learning during the second year of National Preparatory School (High School); (2) The literary texts were the excuse to recreate contents like mining, periodic table, metals, semimetals and non metals and their location in the periodic table, and also the conservation or destruction of our planet: reduction, reuse and recycling of garbage (Unit 4 of chemistry III program "Earth crust: useful materials for the man"); (3) Second year study programs were analyzed to see which other subjects and contents the literary texts would be related to; (4) There was a rehearsal with the groups 552 and 553; (5) "A musical, literary, ecological and chemical show” was presented [2].

The activities are displayed in the order they were 
done. The first five activities were in charge of group 553, and the other five were done by group 552 and both groups took part in one activity.

\section{Results and Discussion}

Most of the activities were adapted by this article author. The links between the different subjects were:

\subsection{Results}

(1) "Bible texts (Book of Job 28) related with the earth crust”. There was a dramatized reading with four students. In this activity, reading skills were developed, and these are related to universal literature (second year) [3]. Two students played instruments (violin and piano) and two students performed an original coreography of contemporary dance that they learned in the dance class, in aesthetic and artistic education subject ${ }^{1}$. The relation with chemistry III was shown in the Old Testament of Job Book 28 because it talks about mining, noble metals, gemstones [4]. The relationship with universal literature is given in the first unit called "Eastern literature in ancient times". The content description establishes "Babylonian-sumerian and Hebrew texts". Compilation and management were in charge of María de los Ángeles Montiel M;

(2) "Elementary chemistry". Rap song composed by a student of group 553. The song was related to chemistry, its study and some characters who have been involved in its development. With this activity, there is a close connection between chemistry and aesthetic and artistic education;

(3) "Aura, a chemical parody of Carlos Fuentes book". Dramatized reading of two students and guitar music played by one student. Carlos Fuentes book is part of the bibliography that students read in Iberoamerican and Mexican literature, in Unit 8 (third year) [5]. The writer of the parody is María de los

\footnotetext{
1 Esthetic and artistic education involves four disciplines: plastic arts, dance, music and theater, which are taught in the first and second years of National Preparatory School.
}

Ángeles Montiel M. Aura is part of the reactants and Consuelo is part of the products. There is a reversible reaction in which the lover will be the displacement factor of the reaction according to the Le Chatelier principle. "Consuelo, the old woman stays in Earth and Aura travels to outer space to stay young" [6]. This proposal does not match the transversality because this should be part of activities in the third year. Besides, reactions in equilibrum belong to Unit 1 "Vital Fluids" of chemistry IV, area 2, in the content 1.2.2. Equilibrum, constant and Le Chatelier principle. In chemistry IV, area 1, it belongs to Unit 2 "Speed and equilibrum in the chemical reactions" and the content 2.2. Chemical equilibrum, 2.2.4. Le Chatelier principle [7];

(4) "Iron and gold”. Story of Ricardo Flores Magón [8]. Dramatized reading of four students who put into practice the reading skills (Spanish) and dramatic art. This activity is related to Iberoamerican and Mexican literature (third year), in the content: socioeconomical and historical context of the first half of XX century in the Unit 7 (avant-garde) and the subject history II, in the Unit 5: México in Porfirio Díaz government (1876 to 1911) in the content 4. Opposition movements to Díaz government: Mexican liberal party (Camilo Arriaga, Flores Magón) [5];

Gold represents the middle class, the kings, the high ranking military. Iron represents the working class in charge of the country development. The text talks about the uses of the two metals that are studied in Unit 4 of chemistry III program "Earth crust: useful materials for the man”. 4.1.1. Minerals, the clue for civilization? [9]. There is a video that displays the uses of iron and gold. This video is related with computing (first year) and the development of information technology, which is one of the pillars asked by the SADE. There is a musical background of a guitar played by a student who is learning how to play it in the music class;

(5) "Playing with the periodic table: (a) place the element in its box; (b) greek or latin?” 
Four students built a giant table in which the elements are given to the students and they had to place them in the correct box according to the family and period. Another part was to get the etymological origin of the chemical element and a bulb was lit if the student was correct. This activity was coordinated by the chemistry and etymology teachers [10];

(6) "Chemical demonstrations" only belongs to chemistry III. The students made a research about the experiments. In this way, they developed experimental skills. Some students commented that the experiments were interesting, colourful, funny, awesome and that it is an interactive and didactic way to learn chemistry;

(7) Dramatized reading of the play "Teleportation from Tacubaya to Classic Greece”. Six students took part in it. The central idea was to follow the instructions in the handling of chemical substances in the lab and to know the toxicity of some substances.
In this play, there are some concepts related to the subjects: etymology (used greek terms), universal history, health science. The play was written by María de los Ángeles Montiel M. [11];

Numbers (8) "Chemistry jokes" and (9) "Chemistry memes", are related with contents of chemistry III and computing (first year). Students need skills to get information in the web and they have to prepare a power point presentation, Unit 3 of computing subject [12];

(10) “Green fashion”. Parade of recycled objects made by the students, so the people can be aware of the environmental care. This topic is studied in the subjects chemistry III [9] and biology IV [13];

(11) "Hanged elements". A team cooked cookies with the shape of the element symbols, and then the students had to write the name of the element.

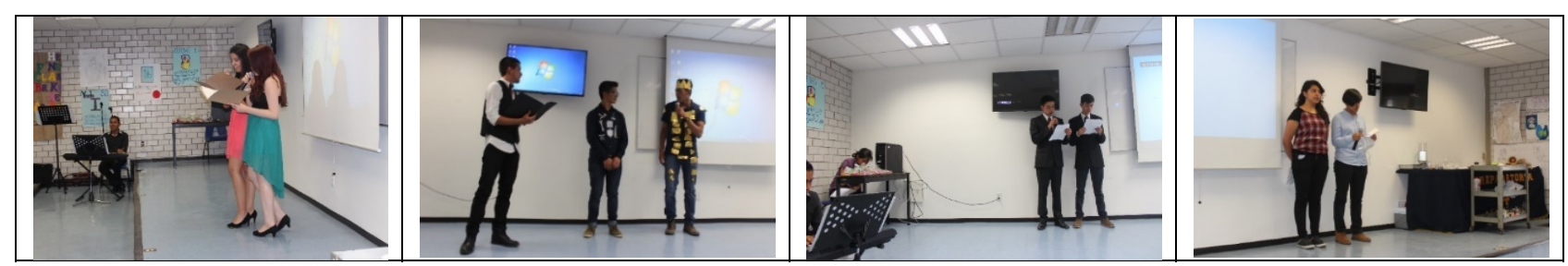

Fig. 1 The reading of literary texts was present during Chemistry Week.
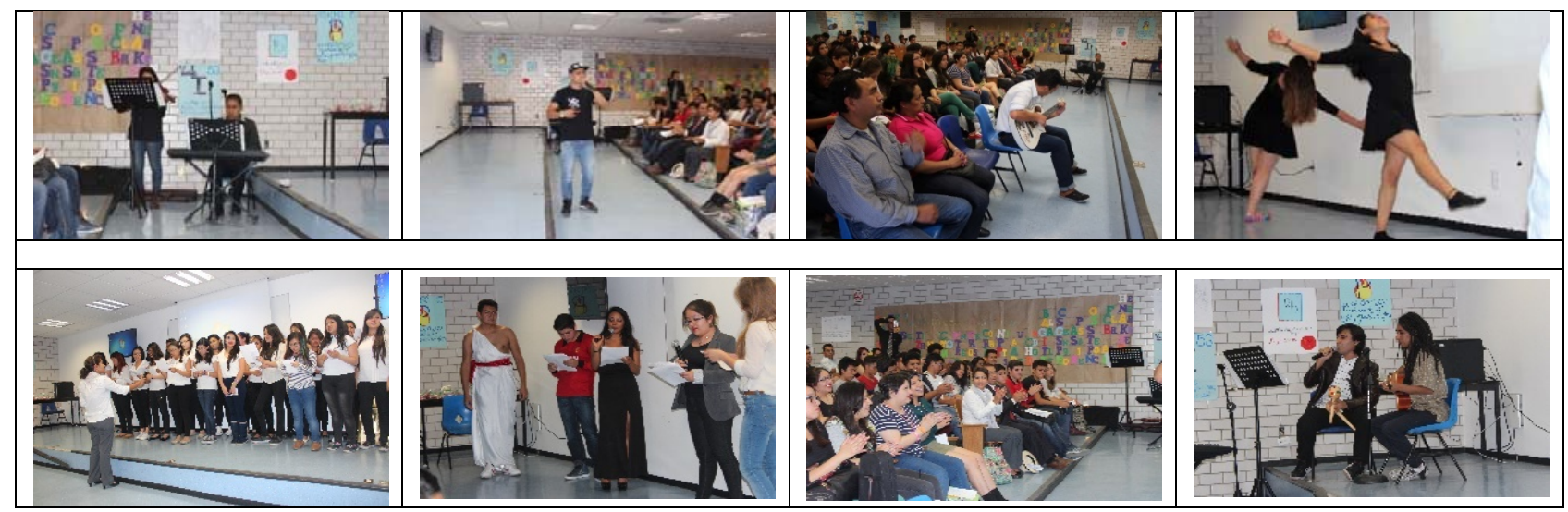

Fig. 2 Music, song, dance and theater liven up a literary work that is related to chemistry.

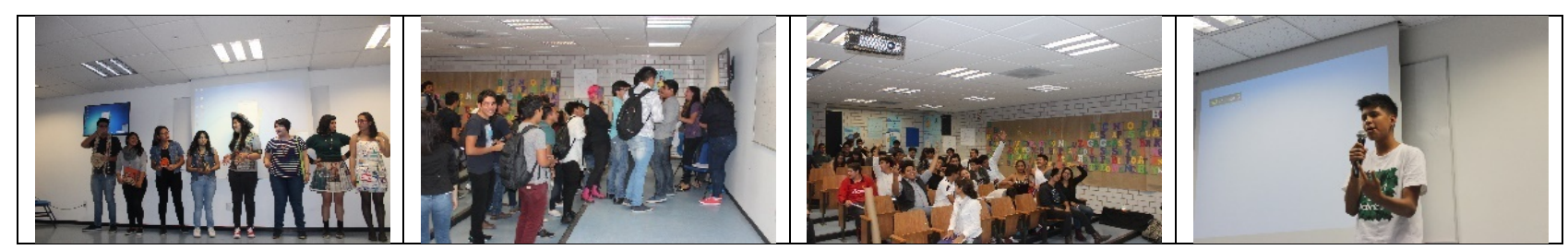

Fig. 3 Even the chemical, and ecological part is fun, the chemical memes and jokes more. 


\subsection{Discussion or Result Analysis}

The axes involved in this proposal were: (1) Reading of texts "to learn and to think" in: Bible texts, story "Iron and gold", "Aura, a chemical parody of Carlos Fuentes book", play "Teleportation from Tacubaya to Classic Greece”; (2) Skills for research and problem solution: "Chemical Demonstrations", "Periodic Table: greek or latin”, "Elementary Chemistry”; (3) Learning and knowledge construction: information technology, "Chemistry jokes", "Chemistry memes", video "Iron and gold" and (4) Value formation: solidarity, team work, discipline, responsibility, respect for the work of others.

The transversal subjects were: chemistry, Greco-Latin etymologies, literature and aesthetic activities, biology IV, health science and history II.

\section{Conclusions}

The students were the builders of their own learning and the recreation of the literary texts that were read with live music. Each student showed the histrionic potentialities and creativity. They also learned chemistry in a meaningful way and had a lot of fun. The students got through the personal experience of understanding that the chemistry is everywhere and that the chemical concepts are related to the study plan subjects that were considered in a multidisciplinary way.

With these activities, the students developed knowledge, abilities and skills through strategies with a multidisciplinary view. Students also stimulated the participatory attitude and the teacher made didactic innovation based on aspects like the transversal proposal.

\section{References}

[1] National Preparatory School. Guidelines in Seminar on Analysis and Development of Teaching (SADE) 2015-2016. Accessed May 2017, www.proyectomc.dgenp.unam.mx.

[2] National Preparatory School. Plans and Study Programs. Accessed May 2017, http://www.dgenp.unam.mx/planesdeestudio/index.html.

[3] National Preparatory School. Plans and Study Programs. Accessed May 2017, http://www.dgenp.unam.mx/planesdeestudio/quinto/1516 .pdf.

[4] Old Testament Book of Job 28. Accessed May 2017, https://www.bibliaenlinea.org/job-28.

[5] National Preparatory School. Plans and Study Programs. Accessed April 2016, http://www.dgenp.unam.mx/planesdeestudio/sexto/1602. pdf.

[6] Montiel, M. A. 2016. Aura, a Chemical Parody of Carlos Fuentes, adapted from the work of Fuentes, Carlos. (1962). Aura. México: ERA.

[7] National Preparatory School. Accessed May 2017, http://www.dgenp.unam.mx/planesdeestudio/sexto/1622. pdf.

[8] Flores Magón, R. 1915. Iron and Gold. Regeneration, number 209, 2. Accessed April 2016, http://bsolot.info/wp-content/uploads/2011/04/Flores_Ma gon_Ricardo-Cuentos_revolucionarios.pdf.

[9] National Preparatory School. Accessed May 2017, http://www.dgenp.unam.mx/planesdeestudio/quinto/1501 .pdf.

[10] National Preparatory School. Accessed May 2017, http://www.dgenp.unam.mx/planesdeestudio/quinto/1505 .pdf.

[11] Montiel, M. A. 2015. Teleportation from Tacubaya to Classic Greece. Unpublished text.

[12] National Preparatory School. Accessed May, 2017 http://www.dgenp.unam.mx/planesdeestudio/cuarto/1412. pdf.

[13] National Preparatory School. Accessed May 2017, http://www.dgenp.unam.mx/planesdeestudio/quinto/1502 .pdf. 